\title{
Empowerment of Local Woman as Initiator of Supporting Space for Tourism, Case Study: Widuri Beach, Pemalang, Indonesia
}

\author{
Suzanna Ratih Sari ${ }^{1 *}$, Rina Kurniati ${ }^{2}$, Muhammad Fariz Hilmy ${ }^{3}$ \\ \{ratihsaris@yahoo.com ${ }^{1}, \underline{\text { adalerina_66@yahoo.com }}{ }^{2}$, farizhilmym@gmail.com ${ }^{3}$ \}
}

Department of Architecture, Diponegoro University ${ }^{1,3}$, Department of Urban Planning, Diponegoro University ${ }^{2}$

\begin{abstract}
Widuri beach is one of tourist destinations in Pemalang Regency. As a consequence, there would be several supporting tourist spaces created to support the tourism activities. However, the supporting tourist spaces are currently in improper condition, especially related to their arrangement in the beach area until the problems related to the tourism development program, sapta pesona. While women's awareness related to the creation of supporting tourist spaces in Widuri tourist area is very lacking. Thus, through this research, there will be studied supporting tourist spaces created by the participation of local women, as well as their arrangement, sustainability, and the increased awareness specifically regarding sapta pesona. By using qualitative method, researchers are expected to disentangle in detail phenomena related to women's participation and supporting tourist spaces, as well as strategies to increase women's awareness in environmental quality and make sustainable tourism activities on Widuri beach.
\end{abstract}

Keywords: local woman empowerment, tourism development, sapta pesona

\section{Introduction}

Tourism development in Widuri beach is a requirement to bring in and to increase tourist visits as well as to increase national income. For most people, tourism has become a necessity that must be fulfilled to free from boredom due to routine daily activities. Based on Law of the Republic Indonesia number 10 of 2009 concerning tourism [1], it is stated that tourism is various tourism activities supported by various facilities as well as those provided by the community, businessmen, government and local government. In addition, various complex sectors such as handicrafts and souvenirs, lodging, and transportation are also economically regarded as industries. In this case, community participation becomes the most important factor for tourism development in a tourist destination. Community participation is distinguished based on gender. In general, gender can be defined as differences in roles, positions, and traits attached to men and women through social and cultural construction [2]. The roles played by men and women must be different because of differences found in gender characteristics between both of them, i.e. men with their rational characters, while women have irrational or emotional characters [3]. These differences make the performance of tourism development becomes more optimal. However, the success of community-based tourism is lacking because of minor participation of the women [4]. Therefore, women's participation is important for the success of community-based tourism [5].

The reason that encourages the establishment of community-based tourism places is the chance, opportunity, and motivation of the community to improve their welfare while preserving their local wisdom. [6]. The problem is that Pemalang Regency has many tourism attractions, but it has never been maintained because there is no participation from local organizations to care for and preserve these attractions. The participation of the community there, especially among women, also took part in tourism activities in the Widuri Beach area, but these activities were not well accommodated and resulting in the emergence of new spaces that did not initially exist. These spaces are initiated and created by mostly women in this area. But even though these spaces have been formed, these spaces are not formed with the rules of comfort and beauty as stated in the principle of sapta pesona. As an initiator, women are often not respected, especially in terms of management of tourism businesses and creation of supporting tourist spaces. Therefore, in this study, researchers are willing to observe the women's role in tourism development by looking at the sapta pesona values which are factors that must be considered in every single step of tourism development and preservation.

\section{Methodology}

This study used qualitative method, i.e. research is conducted in-depth and in detail way on a research object to observe the development of the region, environment, and changes found in the object [7]. In this study, 
Widuri Park in Widuri beach is an object that experienced changes in the provision of tourism facilities made by community groups. The primary data generated is obtained by conducting in-depth interviews with stakeholders who are considered to have a lot of experience and knowledge regarding Widuri beach. For data collection, researchers use Forum Group Discussion method to gather information needed in this research. Observations and documentation were also carried out to provide visualization of problems at the research site. Diagram 1 is illustrated the structure of research study to consider the important indicator of the research which has a deep impact on discussion of the phenomena related to Local Women Empowerment in Widuri beach.

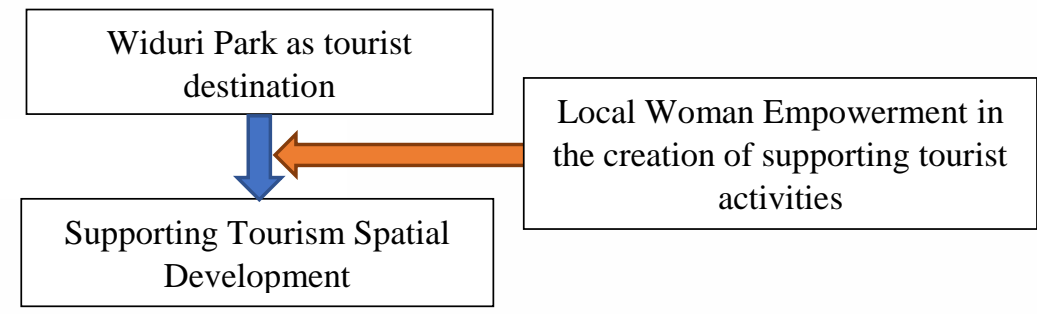

Diagram 1 Structure of research study Source: Developed by Author, 2019

\section{Result and Discussion}

\section{Widuri Beach as Tourism Destination}

Tourism is classified into several types including cultural tourism, marine tourism, nature reserve tourism, and so on [8]. One of the tourism attractions that are in great demand by domestic and foreign people is beach tourism. This is like one of the beaches in Pemalang Regency, Widuri beach still becomes a favorite attraction for tourists until now. Located on the north side of Java Island (see figure 1), Widuri Beach is one of many beaches on the north coast of Java which offers beautiful scenery like other beaches around it. The beautiful scenery offered by this beach is outstretched with a row of Angsana trees along the shoreline. In addition to its natural attractions, there is also another kind of attractions exist in Widuri Beach, called Widuri Water Park. This park is artificial that offering various water games, with facilities and services still being improved. Besides enjoying the beautiful scenery of the beach, tourists also can do swimming, fishing, kite playing, beach sports, jogging, etc.

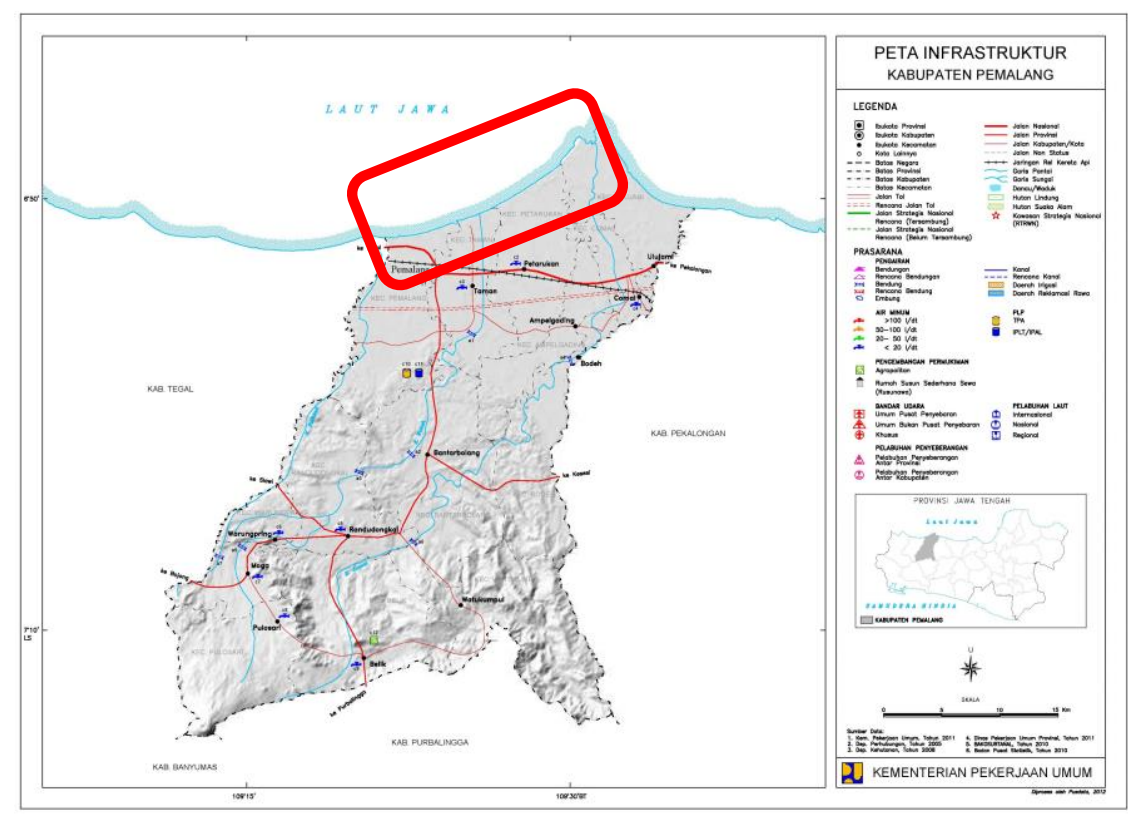

Figure 1 Map of Pemalang Regency and Widuri Beach Source: [9]

At certain times, this beach will be very full of visitors such as on Eid holidays or other national holidays. Not only crowded with tourists, but local residents also come and even conduct tourism activities blend together with the tourists such as selling food and local products. This makes the condition of the beach becomes more 
crowded and creates new spaces for accommodating those activities which previously did not exist. The new spaces usually occupied areas were not functioned as commercial areas before. Therefore, almost all areas covered with tourist activities and even supporting facilities. The formations of these spaces themselves are not well maintained and well managed, due to the lack of regulation from tourism Board and role of pokdarwis (local community group that concerned about tourism). Hence, people are creating new spaces and build their temporarily building as they like. Forms of new spaces in that area include food court area, handicraft and souvenir shops, sitting groups, and other supporting areas such as selfie spots that spread in some tourist areas (see figure 2).
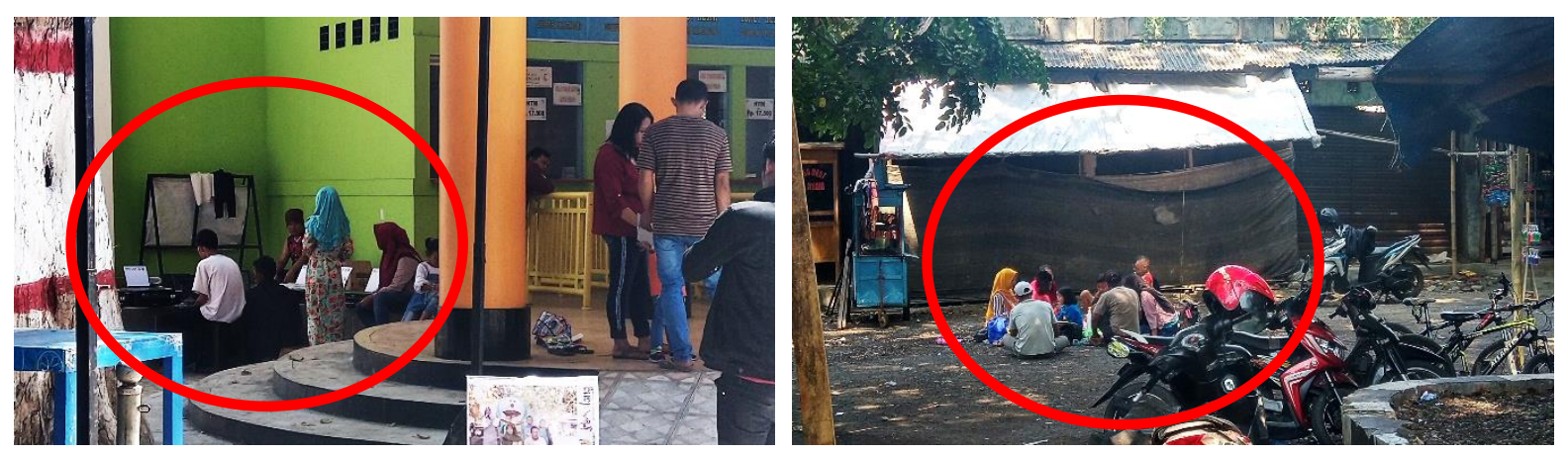

Figure 2 Spaces formed in the beach area

Source: Personal Documentation, 2019

However, some problems might arise especially after these people occupied the areas. It become difficult mostly when they were asked to move or anyone else use the area for other functions. They actually should responsible for planning and managing their environment, but in reality they do not care about that matter. Some efforts need to be made so that these entrepreneurs can play an active role in making decisions about the forms of tourism facilities in their occupied spaces as they need and as they want in a proper way. The involvement and participation of women in tourism development and management in tourism business is an important factor because women often more understand and master the conditions in their tourist areas rather men. Therefore, as in the case of Widuri Park, women are domination in running tourism industries compare to men.

\section{Local Women Empowerment in Widuri Park}

The partnership between men and women is one of the development strategies carried out to achieve gender equality and justice by integrating the experiences, aspirations, needs and problems of men and women into planning, implementing, monitoring, and evaluating all policies, programs, projects and activities in various fields of life and development [10]. In order to bring into harmonious between women and men, women must pursue various disadvantages from men with various steps that must be taken. The related steps are increasing women's capacity, population, access to development, welfare, independence, as well as mental and spiritual resilience [11]. In this research, women's involvement in tourism can reduce gender inequality specifically in tourism development [12]. It means that women actually destined as a housewife and stay at home, but in the case of this research, women have a role in defining the space that they can use for economic space and these women have power to control the management and the use of that space.

The existence of women in community life is not only in a development process but also as a strong structured foundation [13]. The same thing was stated by the ministry of women's empowerment and child protection of the Republic of Indonesia [14] that there was a lot of evidence showed the role of women as a key factor in developing socio-economic conditions. In this study, economic factors are also included in tourism development goals. Tourism activities have encouraged various kinds of activities such as cultural and economic activities in a tourism area, this required the provision of some spaces to accommodate those activities. In creating supporting tourist space, there are several steps that can be conducted [11] include WID (Women in Development) which is a program prepared to increase women's role that focuses on efforts to catch up with women; WAD (Women and Development) which focused on activities that bring in women's incomes and less focus on women's power which is encouraged in maintaining families and households; and GAD (Gender and Development) focused on the pattern of relationships that are equal for women and men. Of the three approaches, GAD is considered as the most accurate approach related to the space created for women, because this approach is done by looking at women as the subject of development so that the experience and understanding of women become the entry point of the development process itself.

Based on GAD Approach, it can be observed that women are involved in tourism activities and the provision of supporting tourism facilities, such as attractions facilities, public facilities, accessibility, and ticketing. While the development of tourism facilities carried out by women will reflect the characteristics of 
women. Some of the characteristics of women that are widely demanded and assessed by the wider community include beauty, tenderness, and humility [15]. The nature of beauty itself not only about the physical but also the beauty of the non-physical or personality of the woman [16]. In designing tourism activities and supporting tourist facilities, women usually concern about beauty. But this is precisely inversely proportional to what was seen in the Widuri park because the conditions there are far from the "beautiful" word. Not because the beach is not beautiful, but because of the activities and facilities around the beach carried out by women which impacted the beach area. There are several acticities (cultural, economic and recreation) taken by women that required supporting facilities, such as the following:

1. Women have role in the implementation of tourism activities. This can be seen when women facilitate various needs of tourists in the Widuri beach area. The main activity they do is selling both food and beverages, as well as they prepared stalls by men's assistance, provide kitchen equipment, cooking, serving food and cleaning after everything is finished (see figure 3). All of this was done by the women themselves without any help from men. The women carried out their economic activities and developed facilities to support their activities along the beach, main corridor, sidewalks or pedestrian. Usually women build temporary stall that easily disassembly after the beach closed.
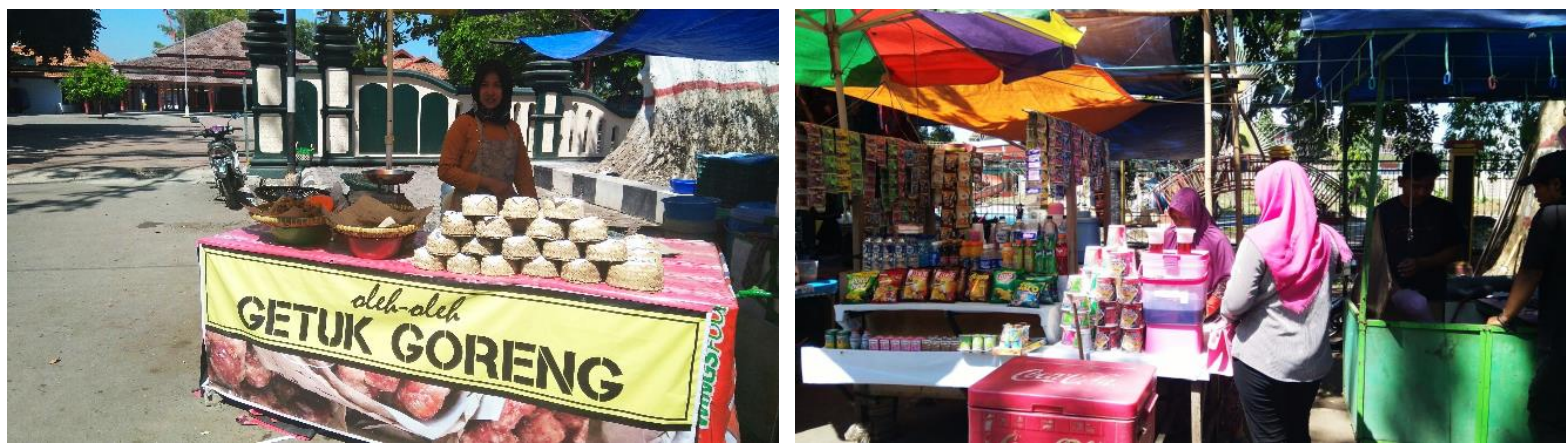

Figure 3 Women create spaces to sell foods and beverages Source: Personal Documentation, 2019

2. In addition to selling food, women also create space for selling local souvenirs (see figure 4). They build temporary and very simple stall by using tarp and table, They even used any vacant space to sell create the stall. These spaces formed certainly not far from the area where others selling food, and they sell side by side without seeing their selling products. They put all of their products as it was, they never thought about aesthetic, attractiveness and creativity in arranging their product. The souvenirs offered by women are artworks from their own creation, handicrafts from bamboo or wood for display, toys for children, beads that are shaped into bracelets or necklaces.
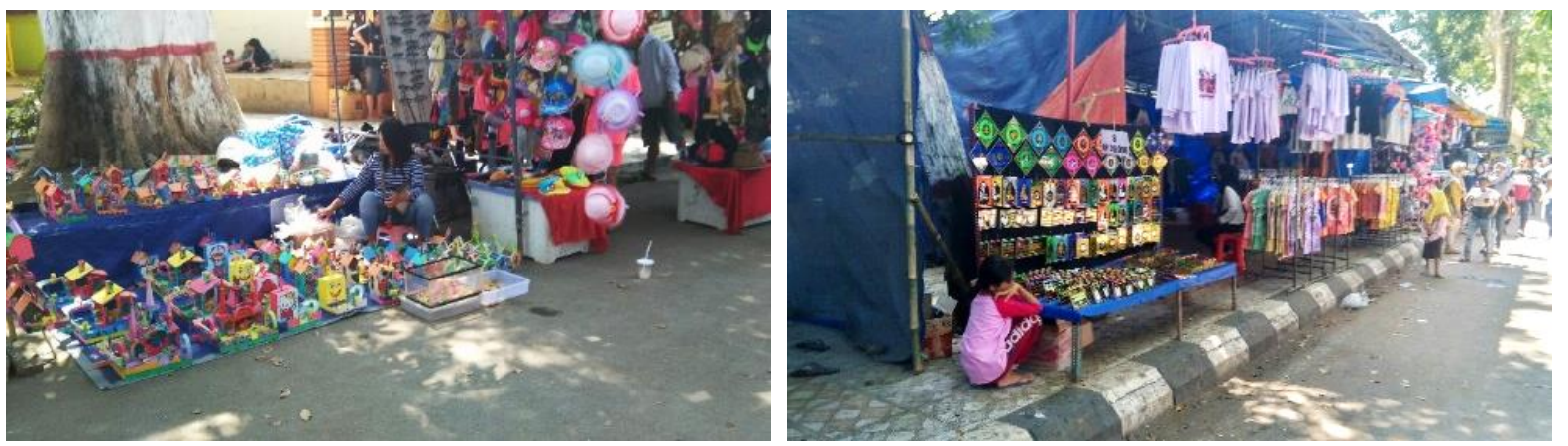

Figure 4 Women form a space for selling souvenirs Source: Personal Documentation, 2019

3. Women's role in the presentation of cultural attractions is carried out at certain events, such as events held by the Pemalang District Tourism Board. They usually perform such as regional dances and singing on stage, etc. This shows that women dominated almost all of supporting tourist activities and most of them are using area provided, not just selling or doing activities behind the scenes. The creation of these spaces for this activity is certainly from the contribution of women's ideas who use the vacant land in the area of Widuri beach for entertaining tourists (see figure 5). 

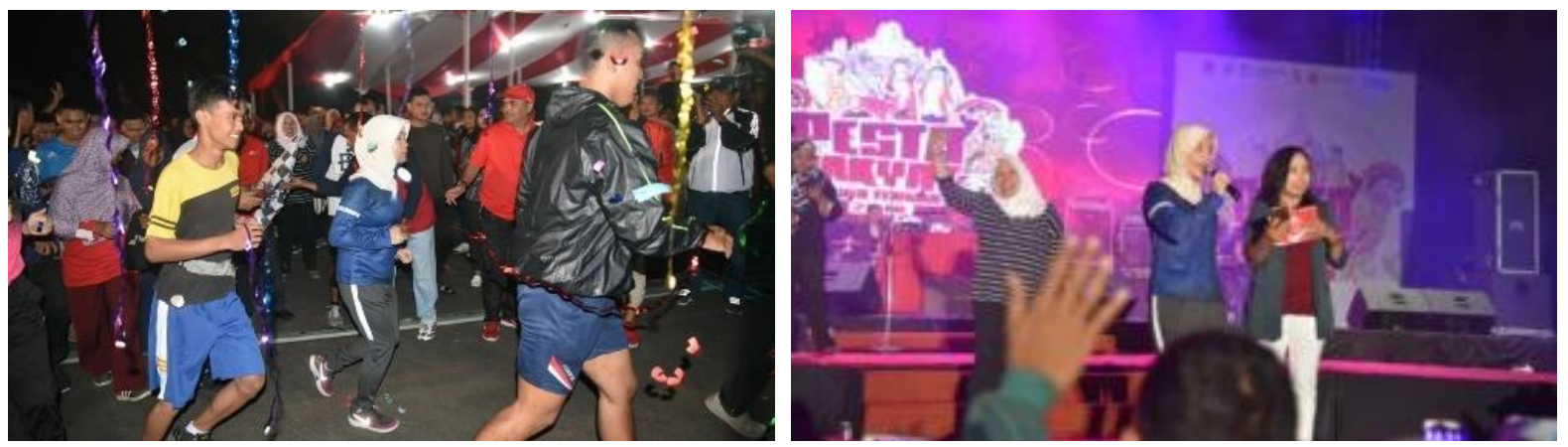

Figure 5 Women do some attractions Source: google image, 2019

In terms of cultural attraction, many women are involved in hamlet or village, for example, cultural parade namely "gunungan" which made from cash crops and potential cultural arts such as exhibitions of creative culture costumes typical of Pemalang Regency (see figure 6). The gunungan of cash crops and the costume exhibition were then paraded as far as $\pm 2 \mathrm{~km}$ around Sabrang Hamlet. The procession of Cultural Parade activity was indeed carried out by men, but the preparation of gunungan and creative cultural costumes for the event the women did, even those who wore the costumes paraded were dominantly women and the others were men Thus, women played a significant role in performing cultural attractions in the Widuri Beach area.
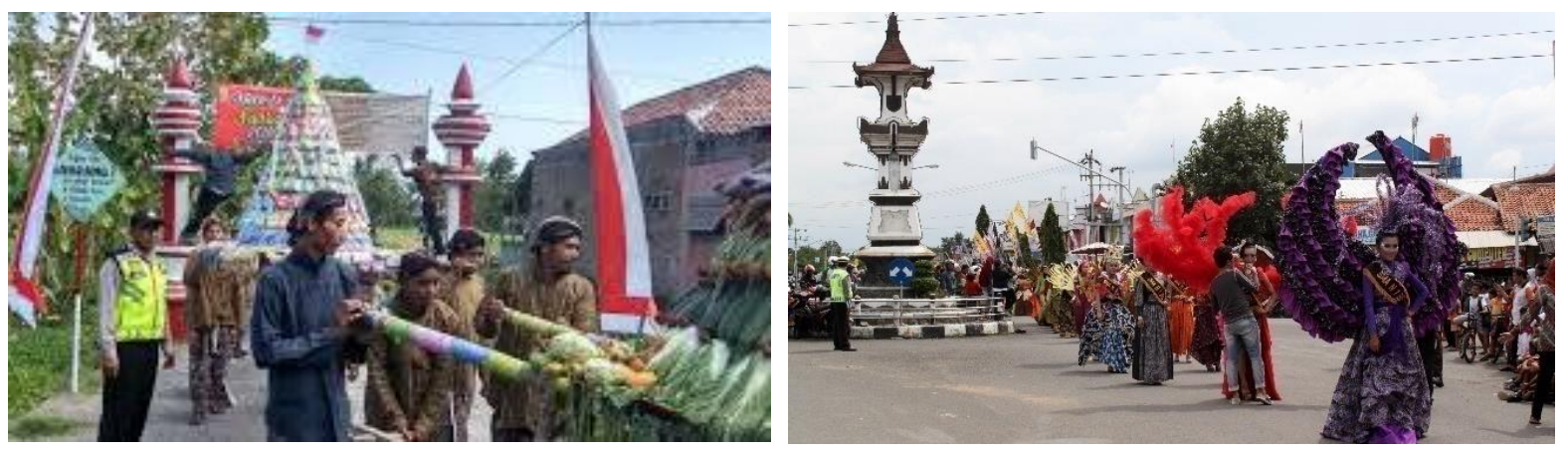

Figure 6 The women conduct Cultural Parade Activity Source: google image, 2019

4. In order to operate a tourism business, women also establish tourist spaces as tourists who come. The women create places for themselves to be able to enjoy their time together with their families by holding mats and serving the food and drinks they brought. The areas chosen by the women included the sidewalk or pedestrian to vacant land under the trees because it was considered comfortable for them to sit on mats and relax under the trees (see figure 7).
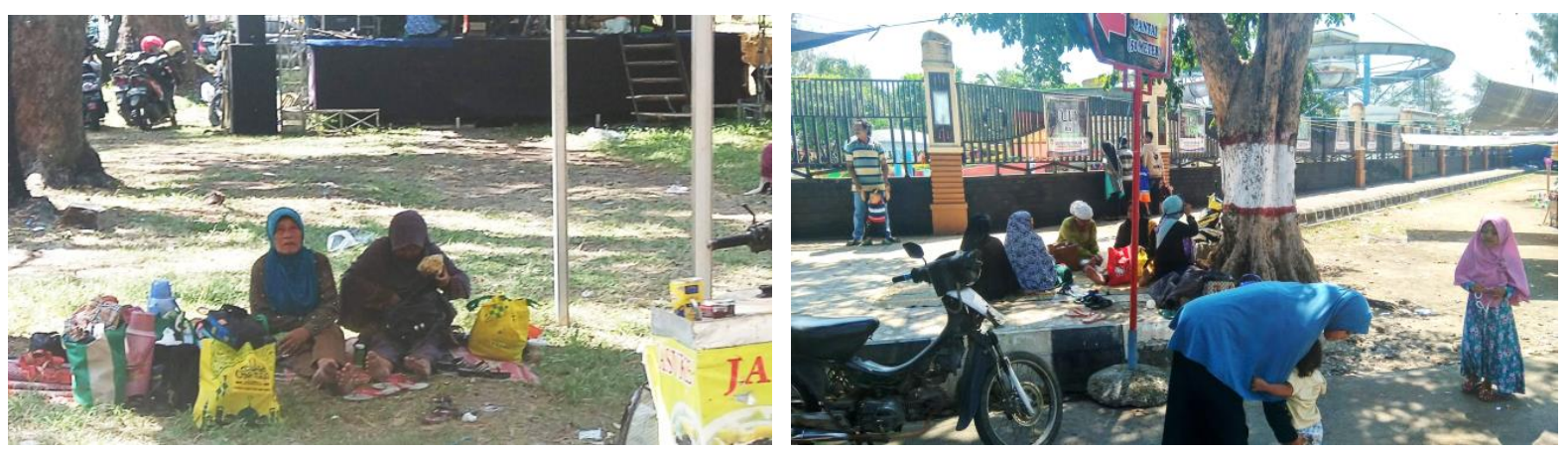

Figure 7 Women create spaces to relax

Source: Personal Documentation, 2019

Besides organizing tourism activities in the sidewalk or pedestrian area, these women use a lot of open spaces and shady trees for them to establish an area where they can trade and relax. The spaces were 
deliberately chosen because the tree area has its special attraction for tourists so that there are quite a lot of tourists who choose this area for trading and relax, especially women who choose these spaces (see figure 8). Therefore, women's role in the formation of space in this tree area is quite significant.
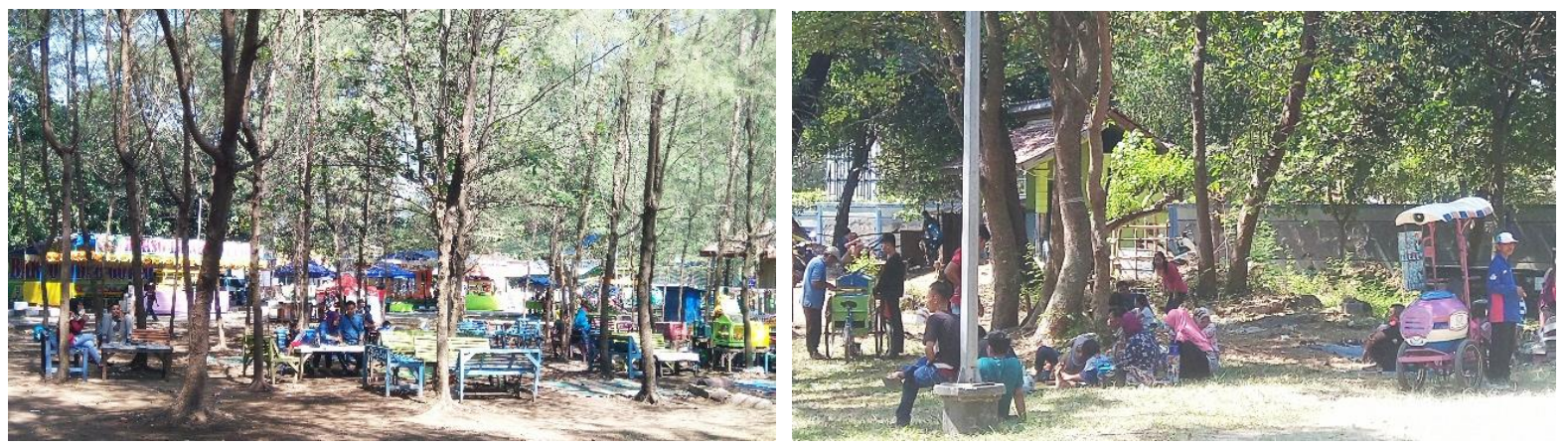

Figure 8 Women form spaces in the tree area Source: Personal Documentation, 2019

5. Another women's activity that influences the use of Widuri Park area is clean up food scraps. They only use area on the back of their food stand. These spaces are adjacent to other spaces like sitting area or relaxing area. It means that the spaces for washing dishes as well as for garbage disposal areas are integrated with people who did eating, relaxing and sitting (see figure 9).
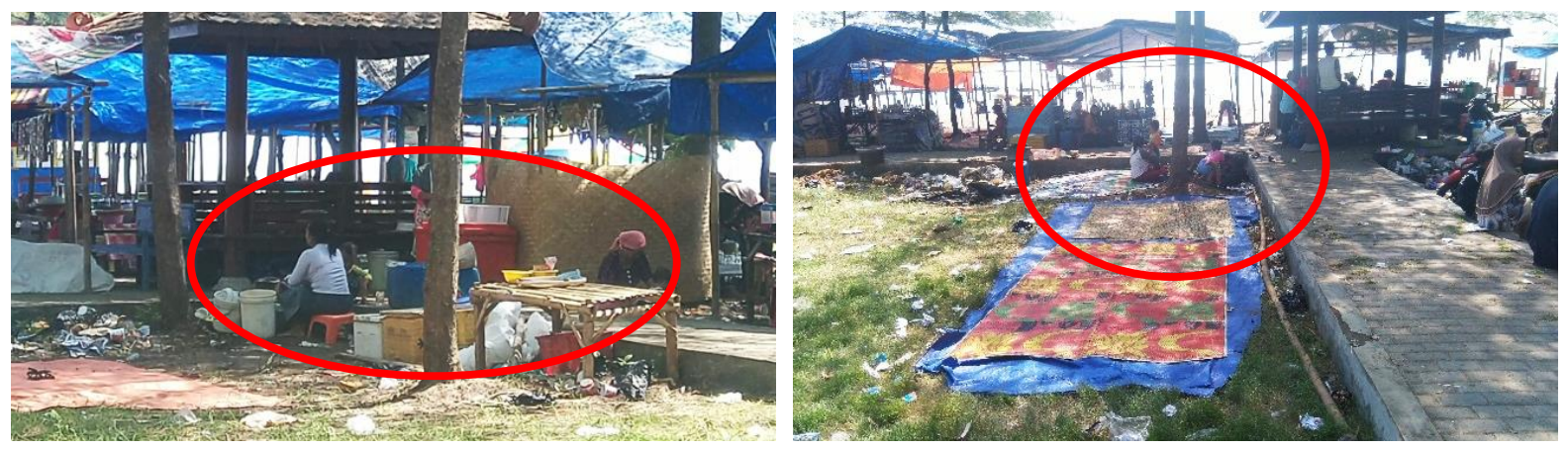

Figure 9 Women create service zones

Source: Personal Documentation, 2019

From the above explanation, it can be said that women's role in organizing tourism activities at Widuri Beach is very significant. It is clearly stated that the impact of the formation of space is occupied as an economic and cultural space for women. The dominance of women in cultural and economic activity made them occupied these spaces and claim those spaces become their territory. Such as the theory of territoriality which states that territoriality is a term associated with nonverbal communication that refers to how people use space (territory) to communicate ownership or occupancy of areas and possessions [17]. Such conditions subsequently resulted in the difficulty of the planned regional arrangement to be carried out by the local office. The following is a diagram 2 that explains the activities and spaces formed from these activities 


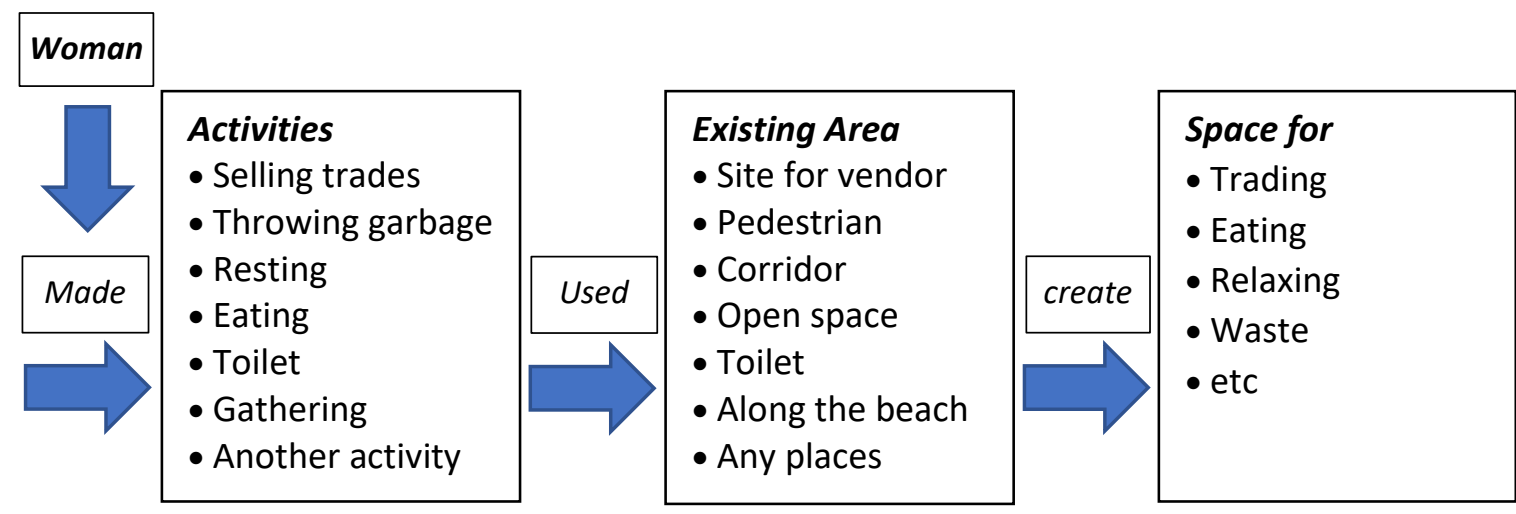

Diagram 2 Space formed due to women's activities source: Developed by author, 2019

The role of women in Widuri park is relatively high in creating tourism activities but not in development. Demartoto (2009) stated about women participation in development. Ideally the involvement and participation of men and women must be equal because both play a role in the development of the tourism area itself. However, the number of women involved in managing community-based tourist areas is minor compared to men. The minim participation of women in the process of tourist area development clearly has various reasons, one of which is the unpreparedness of women in carrying out their role in tourism development. It can be noted that women in the context of tourism activities and the formation of tourist spaces, they are more 1) brave to do something related to tourism activities, 2) creative and have more ideas that can benefit them, 3) dependable and test resistance even though there are often disasters on the Widuri beach but they still exist, 4) responsive, especially to tourism needs, 5) more indifferent, especially to the other people's rules and opinions, because according to them, as long as what they do is good, they will continue their activities even this break the rules. These characters also make women retain the space they create.

Some of the efforts of the government or the local people themselves helped to regulate the spatial layout in the Widuri Beach area to make it more organized, but the women retain the space they created and will not move to another space that might have been prepared. This is certainly contrary to the characteristics of women that have been explained above that women have a subtle character. But in this case, the women became more courageous and had a different side than the existing theory. When compared with men, the difference can be seen, i.e if men are given direction to move immediately or are not allowed to make space in a place that is not supposed to be, then those men will certainly find it easier to accept the prohibition, rather than deny or defend it. But it's different from women. If they are given such direction, then not only one or two women, but most women will argue and question why the space they created must be moved and of course they will retain the space they made without having to know the reason why they were moved first. Such characters make the women in the Widuri Beach area retain the tourist space that they have created so far today.

\section{Tourism Spatial Based on Sapta Pesona}

Tourist spaces based on sapta pesona are spaces formed on the basis of the needs of tourism activities conducted. The spaces created must also considering various aspects that exist in the sapta pesona concept. Sapta pesona is defined as a condition that must be realized for the creation of a conducive environment and ideal for the development of tourism activities in a place that encourages the growth of interest in tourists to visit [18]. The success of the tourism sector itself is inseparable from several supporting elements so that tourists feel comfortable, satisfied and get special memories so they will revisit the area. Sapta pesona began to be commonly used and campaigned as a condition that must be realized in every tourist destination whether it is natural, cultural, artificial or special. This concept is often used to make visitors feel comfortable and get good memories. The Sapta Pesona concept is expected to create a comfortable feeling from the tourist side. One of the destinations which have close correlation with the community is beach tourism. In this destination, the implementation of tourism awareness and Sapta Pesona concepts becomes a crucial matter in the foundation of the development of tourist spaces, because it can encourage public awareness to become a good host preserve the existed tourism attractions.

In addition, the implementation of Sapta Pesona will also increase the position of the community as those who are benefited from the development of tourism activity. The purpose of Sapta Pesona program implemented by the government is to increase awareness, a sense of responsibility for the entire community to be able to act and realize the charm of everyday life, especially to support tourism activities such as one found in 
Widuri Beach. Sapta Pesona is symbolized by a logo of 7 shining suns which symbolize the elements of Security, Order, Cleanliness, Coolness, Beauty, Hospitality, and Memory. Women's role in tourism activities that considering Sapta Pesona especially at Widuri beach is very minimal, although there are many activities supporting tourism activities in the region created by the women themselves. Based on observations that have been conducted to some spaces created by women from tourism activities they do, there are supporting tourist spaces in the coastal area that does not reflect the sapta pesona concept, they are as follows:

1. Space for trading

Women in Widuri beach built temporary buildings or stalls to sell food and drinks. Most of these activities were conducted by residents around the Widuri beach from mothers to daughters. The women formed a space for them for trading, including in the road corridor area, along with the sidewalk or pedestrian, vacant land, until the beach area itself (see figure 10). However, the spaces they create do not reflect beauty, seem slum, unorganized, and unsafe (because at times there can be strong winds and heavy waves). This condition is far from the sapta pesona principles.
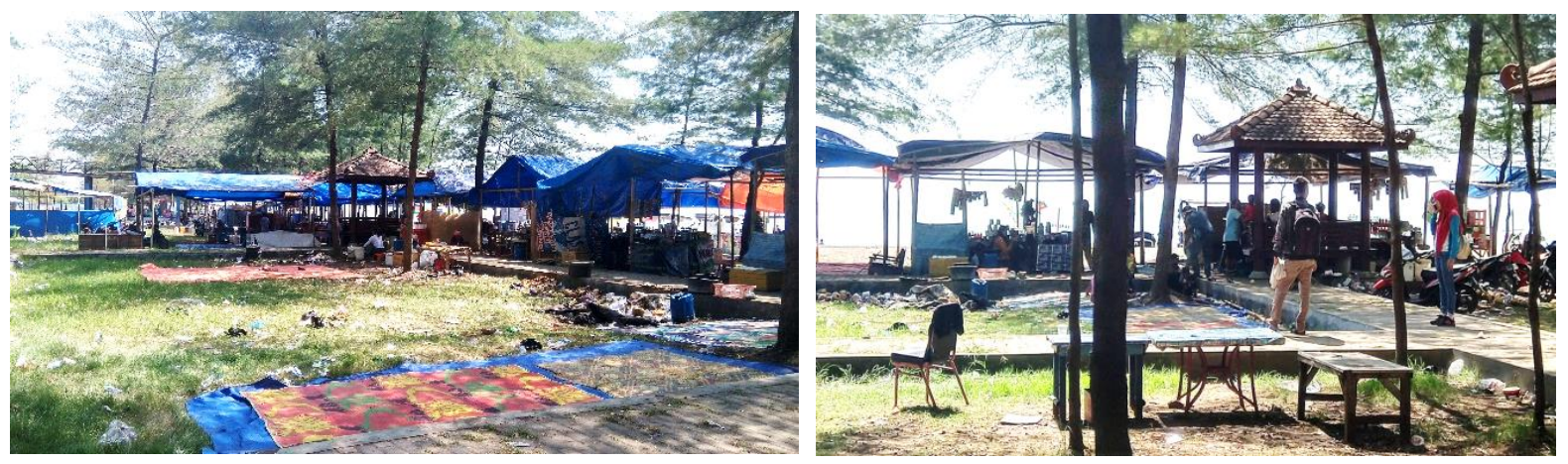

Figure 10 Space for trading that dirty Source: Personal Documentation, 2019

2. Space for eating

In addition to space for trading, of course, there is space to enjoy these foods and drinks, which is space for eating and taking a rest. These spaces are created to facilitate tourist activities while resting and enjoying food served in food stalls. The space they created looks very simple, which is used a makeshift mat and covering with a tarpaulin that prone to the sea breeze. The condition of these spaces are very dusty and mixed with the beach sand and far from hygienic impression. As well as seating facilities and gazebo, they are also not much different from the place to eat on a mat, which is dusty and dirty (see figure 11).
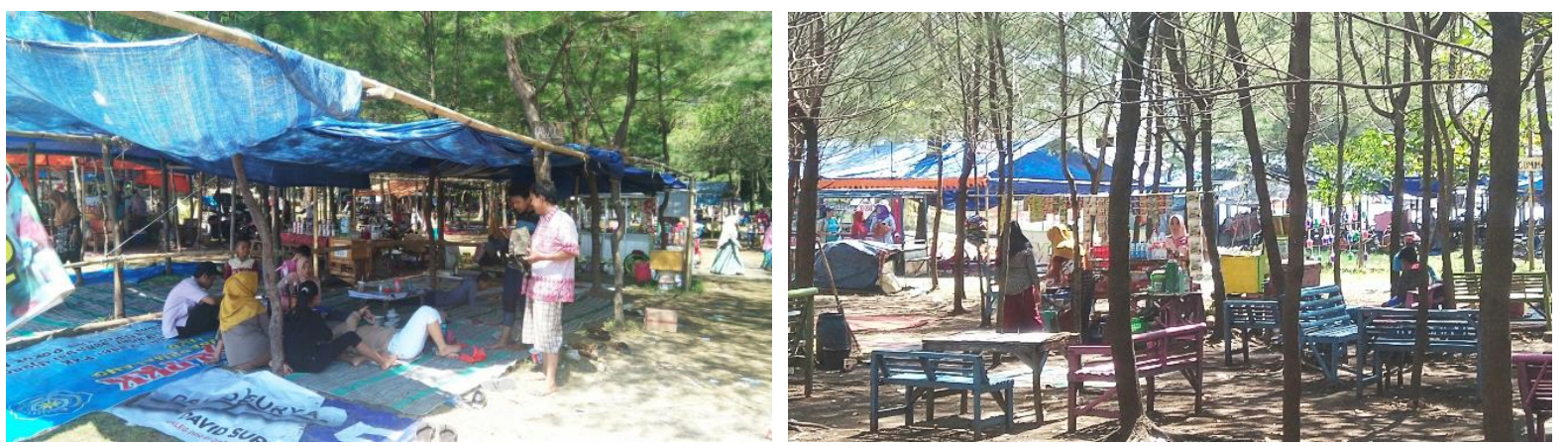

Figure 11 Unhygienic Spaces for Eating

Source: Personal Documentation, 2019

3. Spaces for relaxing

Spaces for relaxing means that women tried to create a place where they can easily take rest after their activities and enjoy their eating and drinking. Some tourists, especially mothers, do their break activities while waiting for their family members enjoying other tourism activities. They use spaces for rest under a tree, pedestrian, parking lots and any open spaces they like and they think are comfortable to do their brake, include public toilet. Some women used mat to create the territory of their space and did their relaxing and some were just sitting and enjoyed their meal together with their family. In this case, it was observed that most ideas to create this space come out from women. Moreover, public toilet usually is improper to utilized as rest area, but women also create rest area in front of public toilet (see figure 12). 
They used this area due to crowdedness and limitation of area that they can use for resting as well as to protect them from the heat. They kept enjoying their resting even though someone else using the toilet, seems like they already occupied that space.
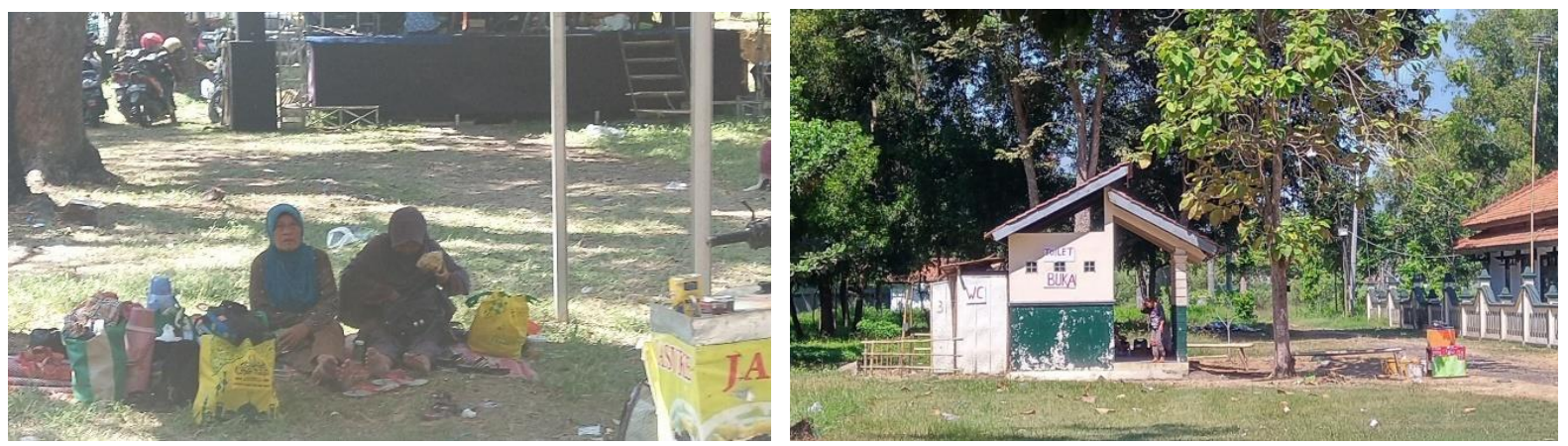

Figure 12 Unhygienic Space for relaxing Source: Personal Documentation, 2019

\section{Spaces for waste}

There are several points of wasting area found in the Widuri beach area. Mostly because people are neglect the important thing to keep their environment healthy and free of waste. The most terrible waste area especially behind the food stalls. The owner uses this area for their service activity such as clean up the dish, throw the garbage and also prepare their food (see figure 13). The women who own this food stall actually aware that they should apply one of the Sapta Pesona's programs which are clean in their food stall and the area surrounding. But in reality they ignore it, they prefer to throw all leftovers and garbage behind their stall area. Such condition will then give an impact of untidiness. Not only service area of the stalls, but in every angle of Widuri Park's area become wasting area included pedestrian and the corridor along the beach. They occupied their territory, but they do not want to take any responsibility toward the cleanness of their spaces. This condition certainly does not reflect the sapta pesona points which should be implemented in this tourist area.
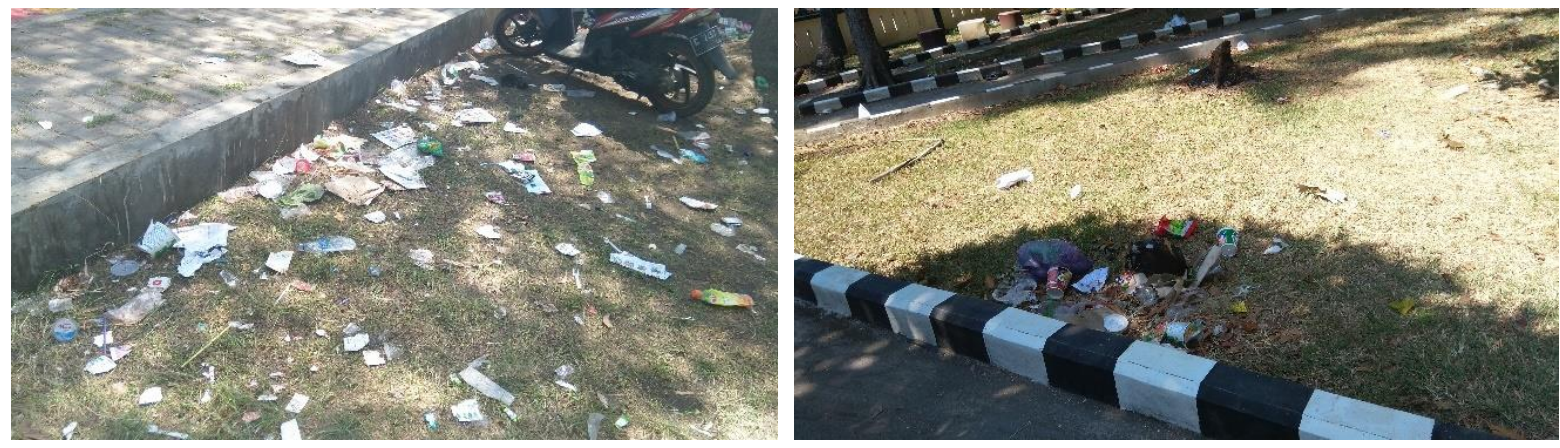

Figure 13 Dirty area of the beach Source: Personal Documentation, 2019

\section{Conclusion}

Based on research had already done in Widuri Park regarding women's activities and women's empowerment specifically in terms of defining supporting tourist spaces. It can be concluded that women in forming tourist spaces in the Widuri Beach area are especially to utilize their supporting tourism activities. Women used spaces in Widuri Park without any exemption to create tourism and economic activities. After that, they occupied these places to become their belonging so that no one could get rid of from these Widuri Park, even though they are illegal. The spaces formed by women such as street vendors spaces, art, and cultural attractions space, spaces for eating, public toilets, rest spaces, and waste spaces. However, most of all are very unworthy, not well-maintained, unattractive and can be said that it is not reflecting the sapta pesona program as guidance for tourism development in Widuri Park and also contradicting with female character, which emphasizes cleanliness and aesthetics. Many of temporarily street vendor stalls looked dirty, poor and very unhygienic. Therefore, lack of public awareness, especially women, certainly requires more attention from 
tourism board to provide an understanding of the creation of supporting tourist spaces that regard the sapta pesona program. To control land ownership, the government must have strict rules to control and structuring tourism areas. Thus, the beauty of Widuri beach will be more interesting and comfortable to enjoy.

Acknowledgment. Thank you very much, I addressed to all who have provided assistance for completing this research. Special thanks to Faculty of Engineering, Diponegoro University which has given researchers with financial support and Pemalang District Tourism Office and several community leaders in the Widuri Park, Pemalang which have also provided any assistance, cooperations, and information regarding this research.

\section{References}

[1] Undang-undang Republik Indonesia Nomor 10 Tahun 2009 Tentang Kepariwisataan, Jakarta: Presiden Republik Indonesia, 2009.

[2] A. E. Manembu, «Peranan Perempuan dalam Pembangunan Masyarakat Desa (Suatu Studi di Desa Maumbi Kecamatan Kalawat Kabupaten Minahasa Utara),» Jurnal Politico, pp. 1-28, 2017.

[3] Rostyaningsih, Konsep Gender, Semarang: LPPM Undip, 2010.

[4] A. Demartoto, Pembangunan Pariwisata Berbasis Masyarakat, Surakarta: Sebelas Maret University Press, 2009.

[5] F. Andani, «Peran Perempuan dalam Kegiatan Pariwisata di Kampung Wisata Tebung Okura Kota Pekanbaru,» JOM FISIP, Vol.4, No.2, pp. 1-11, 2017.

[6] S. A. Wijaya, Zulkarnain dhe Sopingi, «Proses Belajar Kelompok Sadar Wisata (Pokdarwis) dalam Pengembangan Kampoeng Ekowisata,» Jurnal Pendidikan Non Formal Volume XI, No 2, pp. 88-96, 2016.

[7] N. Muhadjir, Metodologi penelitian kualitatif, Yogyakarta: Rake Sarasin, 1996.

[8] I. K. Suwena dhe I. G. N. Widyatmaja, Pengetahuan Dasar Ilmu Pariwisata, Denpasar: Pustaka Larasan, 2017.

[9] K. PUPR, «Peta Infrastuktur Kabupaten Pemalang 2012,» 2016. [Në linjë]. Available: http://loketpeta.pu.go.id/petainfrastruktur-kabupaten-pemalang-2012.

[10] A. S. Djarkasi, «Kemitrasejajaran Gender : Pria dan perempuan dalam pembangunan,» Jurnal AKRAB Vol.1 Edisi 4 , pp. 32-38, 2010.

[11] T. Sofiani, «Membuka Ruang Partisipasi Perempuan dalam Pembangunan,» Muwazah, Vol.1, No.1, pp. 63-71, 2009.

[12] T. Handayani, Sugiarti dhe S. Dharma, Konsep dan Teknik Penelitian Gender, Malang: Universitas Muhammadiyah Malang Press, 2002.

[13] S. N. Batjo, «Eksistensi Perempuan dalam Pembangunan yang Berwawasan Gender,» Populis, Vol.7 No.2, pp. 99-104, 2013.

[14] Kemenpppa, «Kementerian Pemberdayaan Perempuan dan Perlindungan Anak Republik Indonesia,» 23 Februari 2018. [Në linjë]. Available: https://www.kemenpppa.go.id/index.php/page/read/31/1667/kesetaraan-gender-perlu-sinergiantar-kementerian-lembaga-pemerintah-daerah-dan-masyarakat.

[15] R. Wijati, «Kepribadian Tokoh-tokoh Perempuan dalam Novel Perempuan Jogja Karya Achmad Munif,» Universitas Negeri Yogyakarta, Yogyakarta, 2015.

[16] K. Kartono, Psikologi Wanita Mengenal Gadis Remaja dan Wanita Dewasa, Bandung: Mandar Maju, 1992.

[17] S. A. Beebe, S. J. Beebe dhe M. V. Redmond, Interpersonal Communication : Relating to Others, Pearson, 2011.

[18] F. Rahim, Pedoman Kelompok Sadar Wisata, Jakarta: Kementerian Pariwisata dan Ekonomi Kreatif, 2012. 